\title{
Blood Chemistry Value Assesment in Hypodermatosis of Cattle in the Chechen Republic
}

\author{
Sh V Vatsaev¹, A Z Dzhamalova², A M Plieva ${ }^{2,3}$, Z T Baisarova², and \\ A A Saidulaev² \\ ${ }^{1}$ Department of Veterinary Medicine and zoo engineering, Chechen State University, Grozny, \\ Russia \\ ${ }^{2}$ Biological research department, Kh. Ibragimov Complex Institute of the Russian Academy of \\ Sciences, Grozny, Russia \\ ${ }^{3}$ Department of Biology Ingush State University, Magas, Russia
}

Corresponding Author:

Sh V Vatsaev

vac-60@mail.ru

Received: 25 October 2019

Accepted: 15 November 2019

Published: 25 November 2019

Publishing services provided by

Knowledge E

(c) Sh V Vatsaev et al. This

article is distributed under the

terms of the Creative Commons

Attribution License, which

permits unrestricted use and

redistribution provided that the

original author and source are credited.

Selection and Peer-review under the responsibility of the AgroSMART 2019 Conference Committee.

\section{Abstract}

This article is devoted to the problem of cattle hypodermatosis caused by Hypoderma bovis De Geer and Hypoderma lineatum De Villers hypoderma flies. The results of studies of blood chemistry value of cattle diseased with hypodermatosis in the Chechen Republic are revealed in the article. The examination of ten blood samples taken from cattle diseased with animals hypodermatosis showed an increase in the activity of creatinine parameters above normal by $60 \%$ or more, a significant decrease in carotene indicators (within $50 \%$ or more), a relative decrease in crude protein, a decrease in glucose levels, an increase in alkaline phosphatase and alanine-aminotransferase, reduction of the studied reserve alkalinity index vol. \% $\mathrm{CO}_{2}$ from 2 to 5 units (12\%) is lower, in six samples an increase in the activity of immunoglobulin IgA. All this is connected with the complex of pathomorphological changes expressed in the mechanical impact -- traumatization, intoxication and hypersusceptibility of the organism of the infested animal with the development of inflammatory and dystrophic manifestations associated with injuries of muscle cells and tissues, intoxication, and an acid-alkali balance of the body shift in the acidic side (acidosis), pathological liver abnormality or diseases, with the defeat of organs and body systems, edema in different parts of the body, defect of immunoreaction and homeostasis in the body. Information obtained from biochemical screen provide an opportunity to conduct a deeper assessment of homeostasis and the body's ability to self-regulate, promptly and comprehensively diagnosing diseases, study the dynamics of the development of pathological processes and conditions in the body, determine the clinical course and justifiably prescribe a complex of effective household and medical-preventive activities aimed at reducing the economic damage to livestock $[8,10]$.

Keywords: hypodermatosis, homeostasis, creatinine, aspartate aminotransferase, alanine aminotransferase, enzymes, acid-base blood composition.

\section{Introduction}

Hypoderma -- a chronic disease caused by Hypoderma bovis De Geer and Hypoderma S OPEN ACCESS lineatum De Villers hypoderma flies, whose larvae are for a long time, 6 to 9 months, 
parasitic in organs and tissues, injure vital organs, tissues and skin of animals. It is widespread and causes livestock significant economic damage [10].

Bott in the process of migration in the animal's body produce a highly toxic substance hypotermotoxin, which with milk and meat can be eaten by people and have an adverse effect on human health.

Dairy and meat productivity from infest animals is reduced, a weakened livestock population is born, which is exposed to other diseases of a contagious and noncontagious etiology [5].

The study of blood chemistry values has an important diagnostic and prognostic significance, allows monitoring the overall health of animals, the activities of organs and body systems, presumably assess the nature and extent of pathological changes in the body of animals, competently build an effective system of control [1--3].

When the physiological balance in the body (homeostasis) is disturbed, there are conditions for the occurrence and development in various organs and body systems of pathological phenomena of an inflammatory and dystrophic nature, the occurrence of diseases [11].

It was found that the bott of the first stage, penetrating through the skin, cause the growing painful reactions and strong anxiety of the animal. A wound is formed at the site of their penetration, serous exudate is released from it, which dries out after some time and covers the wound with a scab [12].

The general state of animals invaded by the bott deteriorates, the morphological composition of the blood changes, the content of erythrocytes and hemoglobin decreases, the number of white blood cells increases [12].

In the body of animals, parasites exhibit locomotion, expressed in mechanical impact, traumatization of organs and tissues in places of advancement and localization of parasitizing bott. The bott of the first stage of the line and lesser ox warble fly, moving along the large cardiovascular and nervous trunks to the neurocanal into epidural fat and esophagus cause damage to the tissues and wall of the esophagus, rupture of blood vessels with extravasation of exudates and blood cells, irritate the spines of the cuticle, secrete a large number of metabolites, which further leads to the development of intoxication, hypersusceptibility of an invasive animal organism, an allergic and hyperergic reaction with the development of inflammatory and dystrophicl reactions $[9,12]$. 
In different parts of the body (in the eyelids, lips, intermaxillary space, neck, decompression, chest, groin, etc.) of these animals, a clinical picture of pulmonary edema, asphyxia, etc. is demonstrated, sometimes fatality case [4].

There are data of the accumulation of a large number of bott in the invasive animals neurocanal caused hindquarter paralysis. Highly toxic proteolysin secreted by N. bovis larvas that died in the spinal canal, can cause paraplelegia [8, 12].

The metabolic products of parasitic bott have a undeniable pathological impact on the parasite carrier [12].

Moreover, the products of metabolism can xenobiotically affect the tissues and cells of the sick organism, can damage the cells that form histohematogenous barriers, so they become easily permeable, which is accompanied by partial or complete cell death. This is very dangerous, since the cells, deprived of protection, first "get sick" and then may die [7].

It is known that under the influence of parasites a complex of biochemical, pathophysiological, immunological, and pathological changes occurs in the animal body diseased with hypodermatosis [4--6].

Given the above and considering our research interests, we preferred to study and evaluate blood chemistry value in cattle hypodermatosis, during the migration of bott, in order to examine issues on the probable reduction in the body's physiological ability to physiologically regulate and overcome the effects of pathogens functioning of the body, the formation of pathogenetic and sanogenetic factors of the parasitic systems functioning in this disease, the deuteropathy appearance, and also heavier clinical course, especially in the associative disease in cattle.

\section{Methods and Materials}

Expeditionary visits to livestock facilities, using the methods of epizootological, clinical and biochemical research in veterinary medicine were carried out in the course of this research.

Studies were undertaken according to generally accepted methods, and in the foothill zone of the Chechen Republic, in a personal subsidiary farm of a resident of the village "Rubezhnoye" of the Grozny rural region.

For the experiment, 10 diseased cattle in clinical form were selected, regardless of productivity, sex, age and body weight. Animals were selected by clinical examination 
for hypo dermatosis of the livestock. The diagnosis was made out on the basis of the instructions, taking into account the clinical signs.

Blood from cows was taken from the jugular vein in the morning before feeding. For the collection of serum was used $10 \mathrm{ml}$ vacuum tubes for the collection of venous blood as a coagulant which contain BD Vacutainer CAT (Clot Activator Tube). The studies were carried out using an IRF -- 454B2M refractometer (KOMZ, Russia) and a Humalyzer 2000 analyzer, in the state budgetary institution of Krasnodar region "Kropotkinskaya regional veterinary laboratory".

In the process of biochemical studies, the level of creatinine, carotene, total protein, Ca, P, AsAT, AlAT, glucose, Vitamin E, urea, alkalinephosphatase, reserve alkalinity, immunoglobulins $A, G, M$ were determined.

\section{Results}

The research led to the following findings: hypodermatosis is one of the most widespread and causing significant economic damage to livestock among cattle diseases registered in the Chechen Republic.

During these studies, we were guided by the principle that the obtained results will allow us expanding the existing ideas about the pathogenetic and sanogenetic mechanisms of the parasitic system functioning in cattle with hypodermatosis, with the further prospect of their use in the combating this disease practice.

The data of biochemical of cattle diseased with hypodermatosis blood serum analysis are presented in Table 1.

As a result of Creatinphosphokinase indices studies, it has been established that in diseased with hypodermatosis animals an increase in the activity of the enzyme index is noted above the norm.

An increase in creatinine activity indicates the influences of a pathological effect on the organism of sick animals, causing muscle tissue damage, muscle cell breakdown, and their contents entering the blood, intoxication, and dysfunction of organs and body systems.

The research indicates a significant decrease in carotene indices (within $50 \%$ and more).

We believe that a significant decrease in carotene activity below the norm indicates the influences of pathological effects on the organism of sick animals associated with the accumulation in the body of harmful substances, damage at the cellular level, 
cell structure, mucous membranes of the body, skin, hair, and other organs and body systems.

The studies revealed a relative decrease in crude protein, which, in our opinion, is connected to a complex of pathophysiological, pathomorphological, biochemical, and immunological changes.

Most of the samples (nine out of ten) showed a decrease in glucose values.

We believe that hypoglycemia is caused by parasites secreting a large number of metabolites with liver damage, when the glycogen synthesis in it is limited or stops and glucose supply from the liver to the blood, as well as the high glucose consumption for energy purposes, neuro-endocrine system abnormality, which is to maintain blood sugar levels at a certain level.

The survey revealed that the nature of the established vitamin E, urea, calcium and phosphorus indices varied within the limits of physiological normal values, which, from our point of view, is connected to the physiological characteristics of the organisms at the time of the research.

According to the results of diseased animals' examination, an insignificant increase in AspAT (aspartate aminotransferase) in samples No. 3, 8, 9 and a significant increase in sample No. 5 was found, and in other cases, the activity was within the limits of physiologically normal values.

The indicators of alkaline phosphatase in the blood examination showed an increase in their level in eight samples No. 1, 2, 3, 5, 6, 8, 9, 10, and in two samples No. 4, 7 within the limits of physiologically normal values. There is an increase in the level of ALAT together with this enzyme, so we tend to believe that these changes are caused by pathological functioning or liver disease.

In the study of the activity of AIAT (alanine-transferase), it was found that the activity of the enzyme in seven samples No. 2, 3, 5, 6, 8, 9, 10 was significantly increased, and in three samples No. 1, 4, 7 was within the limits of physiologically normal values.

The increase in the systemic exposure of AIAT, in our opinion, associated with destructive diseases in the cells of organs, especially the liver, as well as injuries and hemorrhages in skeletal muscles occurring as a result of the insertion and advancement of hypoderm larvae in the body.

In the process of alkalinity reserve vol. $\% \mathrm{CO}_{2}$ research, there was a decrease in the studied parameter in all samples. That indicates a shift in the acid-base balance of the organism to the acid side (acidosis). 
The decrease in the indicator's activity from 2 to 5 point (12\%) below the norm evidences the pathological effects influence on the organism of sick animals connected to the damage of muscle tissue, other organs and body systems, impaired immunoreaction, in such a condition viruses, bacteria, fungi rapidly proliferate and that is a harbinger to a poor prognosis.

The immunoglobulin IgA values in four samples No. 2, 3, 4 and 9 are within the upper limits of physiologically normal values, and in six samples No. 1, 5, 6, 7, 8, 10 there was an increase in the activity of the indicator, we believe that indicates the pathological effects influence on the organism of animals diseased with hypodermatosis and allows us estimating the potential of the immune response without taking into account the antigen specificity.

Since immunoglobulin $\lg A$ is a protective factor of the mucous membranes and skin, in our opinion, its concentration increase can determine the biological significance of immunoglobulin IgA in the process of protecting the body from the aggressive effects of various pathogenic agents and their neutralization in this disease, and can be traced in autoimmune and lymphoproliferative processes results in the body of sick animals.

Indicators of immunoglobulin -- IgG and immunoglobulin -- IgM noted in the course of the research varied within the limits of physiological normal values, which, in our opinion, reflect the peculiarities of the physiological state of animals during the experimental studies.

\section{Conclusion}

Thus, as a result of the specified literature and our own research data analyzing, the negative effect of hypodermatosis invasion on the organism of affected animals has been established. Decrease in the functional status of organs, body systems and metabolic processes in the body diseased with hypoderma, leads to dyscrasia, reduced body resistance, immunity, impaired ability of the body to self-regulation (sanogenesis), changes in physiological parameters of creatinine, carotene, AcpAT, AIAT, glucose, alkaline phosphatase, reserve alkalinity and immunoglobulin IgA.

As a result of body acidification in cattle hypodermatosis, the following is observed: a change in the body's immunoreaction, which is a contributing factor for the rapid reproduction of pathogenic agents such as viruses, bacteria, fungi; the blood gland, organs and body systems functional depression; physiological misbalance between the subcutaneous water and blood plasma composition, i.e. violation of the optimal 


\begin{tabular}{|c|c|c|c|c|c|c|c|c|c|c|c|}
\hline 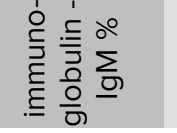 & $\stackrel{\infty}{=}$ & $\stackrel{\circ}{\mathrm{i}}$ & i & $\stackrel{+}{i}$ & $\stackrel{N}{\sim}$ & $\stackrel{m}{\sim}$ & $\stackrel{\llcorner}{\sim}$ & $\stackrel{+}{\sim}$ & $\stackrel{t}{i}$ & $\stackrel{\circ}{i}$ & $\stackrel{\stackrel{N}{m}}{\stackrel{1}{=}}$ \\
\hline 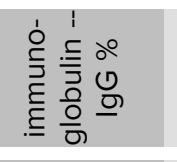 & $\begin{array}{l}\infty \\
\stackrel{\infty}{\curvearrowleft}\end{array}$ & $\stackrel{N}{\stackrel{N}{*}}$ & $\stackrel{\leftrightarrow}{\stackrel{-}{-}}$ & $\begin{array}{l}\stackrel{m}{\infty} \\
\stackrel{\infty}{\infty}\end{array}$ & $\begin{array}{l}\stackrel{\theta}{0} \\
\underline{\varphi}\end{array}$ & $\stackrel{\infty}{\stackrel{-}{-}}$ & $\stackrel{+}{\stackrel{\sigma}{\sigma}}$ & $\begin{array}{l}\infty \\
\infty^{\infty}\end{array}$ & $\stackrel{\varphi}{\stackrel{-}{-}}$ & 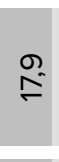 & 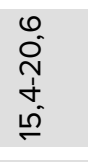 \\
\hline 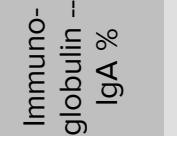 & 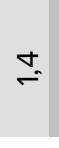 & $\hat{0}$ & $\stackrel{\infty}{\infty}$ & $\stackrel{?}{0}$ & 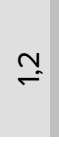 & $\stackrel{0}{\circ}$ & $\stackrel{N}{\sim}$ & $\stackrel{\llcorner}{\sim}$ & $\ddot{0}_{0}^{\circ}$ & $\stackrel{\square}{\circ}$ & $\begin{array}{l}\bar{i} \\
0 \\
0\end{array}$ \\
\hline 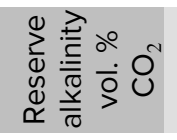 & $\stackrel{\circ}{\stackrel{+}{f}}$ & $\overline{\tilde{\gamma}}$ & $\stackrel{\mathfrak{Y}}{\mathfrak{Y}}$ & 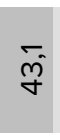 & $\begin{array}{l}\stackrel{\oplus}{q} \\
\text { q }\end{array}$ & $\stackrel{\circ}{\dot{f}}$ & $\stackrel{+}{\stackrel{4}{4}}$ & $\stackrel{0}{\dddot{q}}$ & $\stackrel{\circ}{\underset{\sigma}{\sigma}}$ & $\hat{⿱ 亠 乂}$ & $\begin{array}{l}0 \\
\emptyset \\
\dot{q}\end{array}$ \\
\hline 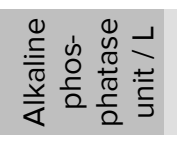 & 先 & 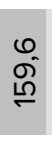 & $\frac{t}{\sigma}$ & $\begin{array}{l}\stackrel{0}{1} \\
\stackrel{N}{ \pm}\end{array}$ & $\begin{array}{l}\text { o } \\
\text { ஸे }\end{array}$ & $\begin{array}{l}\hat{0} \\
\stackrel{0}{\llcorner} \\
\stackrel{n}{\sim}\end{array}$ & $\begin{array}{l}\stackrel{+}{\sim} \\
\text { กิ }\end{array}$ & $\stackrel{\infty}{\stackrel{\infty}{L}}$ & $\begin{array}{l}0 \\
\text { î }\end{array}$ & $\begin{array}{l}\ddot{0} \\
\stackrel{0}{0} \\
\stackrel{1}{n}\end{array}$ & 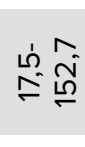 \\
\hline 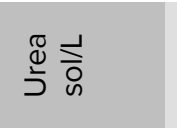 & $\begin{array}{l}\circ \\
\text { เे }\end{array}$ & $\stackrel{\sim}{\sigma}$ & $\stackrel{N}{m}$ & $\stackrel{\sim}{\sim}$ & $\stackrel{\sim}{\sim}$ & $\begin{array}{l}\circ \\
\text { เ) }\end{array}$ & $\stackrel{\infty}{\sim}$ & $\begin{array}{l}\circ \\
\text { ㅇ }\end{array}$ & $\begin{array}{l}\text { \& } \\
\text { Li }\end{array}$ & $\begin{array}{l}\text { ब, } \\
\text { ம) }\end{array}$ & $\begin{array}{l}\infty \\
\infty \\
\infty \\
\infty \\
i \\
i\end{array}$ \\
\hline 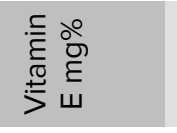 & $\begin{array}{l}\bar{y} \\
0\end{array}$ & 㟔 & 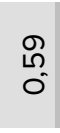 & $\begin{array}{l}\tilde{0} \\
0 \\
0\end{array}$ & $\begin{array}{l}\infty \\
\stackrel{\infty}{1} \\
0\end{array}$ & $\begin{array}{l}\text { กี } \\
\text { กุ } \\
0\end{array}$ & $\begin{array}{l}\mathscr{m} \\
\text { m. }\end{array}$ & $\stackrel{\llcorner}{0}$ & กี & $\begin{array}{l}\text { חొ } \\
\text { ? } \\
0\end{array}$ & $\frac{\substack{t \\
\dot{t}}}{0}$ \\
\hline 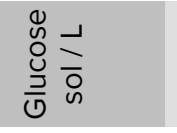 & $\stackrel{0}{\circ}$ & $\stackrel{\infty}{=}$ & $\stackrel{\stackrel{n}{ }}{\stackrel{-}{L}}$ & $\stackrel{\bar{m}}{\sim}$ & $\stackrel{\stackrel{n}{L}}{\sim}$ & 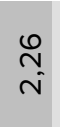 & $\stackrel{\circ}{\stackrel{\infty}{\sim}}$ & $\stackrel{\stackrel{\llcorner}{\infty}}{=}$ & $\underline{\sigma}$ & $\stackrel{\bar{i}}{\bar{i}}$ & $\begin{array}{l}\bar{f} \\
\text { ñ } \\
\sim\end{array}$ \\
\hline 过迹 & $\stackrel{\llcorner}{\stackrel{N}{N}}$ & $\begin{array}{l}\circ \\
\infty_{m}^{\circ}\end{array}$ & $\begin{array}{l}0 \\
\dot{f}\end{array}$ & $\stackrel{\llcorner\Omega}{m}$ & $\stackrel{\infty}{\mathscr{f}}$ & $\stackrel{m}{\sim}$ & $\stackrel{\dot{m}}{m}$ & $\begin{array}{l}\llcorner \\
\tilde{e}^{\circ}\end{array}$ & $\begin{array}{l}\infty \\
\text { ○ं }\end{array}$ & $\hat{\circ}$ & $\begin{array}{l}m \\
\stackrel{m}{n} \\
\omega^{\prime} \\
0\end{array}$ \\
\hline 連号 & 占 & $\begin{array}{l}\stackrel{0}{\tilde{m}} \\
\stackrel{0}{0}\end{array}$ & $\stackrel{\stackrel{\varphi}{0}}{\stackrel{\varphi}{=}}$ & $\begin{array}{l}\llcorner 0 \\
\text { กั }\end{array}$ & 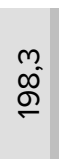 & $\begin{array}{l}m \\
0 \\
\infty\end{array}$ & $\underset{\text { กิ }}{\text { กิ }}$ & $\stackrel{m}{\stackrel{m}{\llcorner}}$ & $\stackrel{\varphi}{\stackrel{\circ}{\rightleftharpoons}}$ & $\stackrel{m}{m}$ & 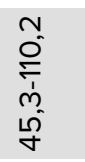 \\
\hline 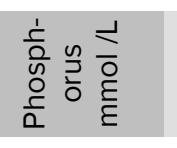 & $\stackrel{\llcorner}{\infty}$ & $\stackrel{\llcorner}{\stackrel{\Omega}{\circ}}$ & $\stackrel{\llcorner}{\sim}$ & $\stackrel{\dot{\sigma}}{i}$ & $\stackrel{n}{\sim}$ & $\frac{\nabla}{i}$ & $\underset{\sim}{\stackrel{\sim}{N}}$ & $\stackrel{m}{i}$ & 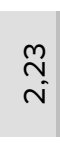 & $\stackrel{\infty}{\infty}$ & $\stackrel{\stackrel{n}{N}}{\stackrel{y}{\leftarrow}}$ \\
\hline $\begin{array}{l}\frac{E}{\bar{u}} \overline{0} \\
\frac{\bar{u}}{\tilde{J}} \\
\mathcal{U}\end{array}$ & $\bar{m}$ & $\begin{array}{l}\stackrel{1}{\infty} \\
\stackrel{\infty}{N}\end{array}$ & $\bar{m}$ & $\stackrel{\circ}{i}$ & $\stackrel{0}{\sim}$ & $\stackrel{\infty}{\sim}$ & $\stackrel{\llcorner}{\sim}$ & $\begin{array}{l}0 \\
i\end{array}$ & $\stackrel{\infty}{i}$ & $\widehat{\sim}$ & $\begin{array}{l}\bar{m} \\
\stackrel{\sim}{n} \\
\sim\end{array}$ \\
\hline 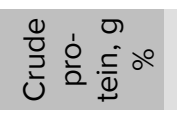 & $0^{\circ}$ & $\begin{array}{l}0 \\
0\end{array}$ & $\hat{\theta}$ & $\hat{\theta}$ & $\ddot{0}$ & $\hat{\wedge}$ & $0_{0}^{\circ}$ & $\begin{array}{l}0 \\
0\end{array}$ & $\stackrel{10}{\varphi^{\circ}}$ & $\stackrel{9}{0}$ & $\begin{array}{l}0 \\
\infty \\
1 \\
N \\
N\end{array}$ \\
\hline 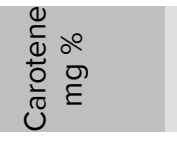 & $\begin{array}{l}\text { Ln } \\
0 \\
0\end{array}$ & $\begin{array}{l}\text { mo } \\
\text { O. }\end{array}$ & $\bar{O}$ & $\begin{array}{l}\infty \\
0 \\
0\end{array}$ & 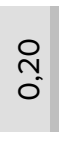 & $\begin{array}{l}\text { ¿ } \\
0\end{array}$ & $\stackrel{\circ}{\circ}$ & $\frac{0}{0}$ & $\stackrel{\circ}{\circ}$ & $\stackrel{m}{\circ}$ & 宪 \\
\hline 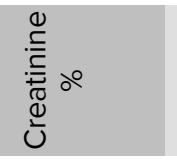 & $\stackrel{\substack{n \\
\stackrel{n}{N}}}{ }$ & $\begin{array}{c}\stackrel{m}{.} \\
\stackrel{0}{\infty} \\
\stackrel{N}{N}\end{array}$ & $\begin{array}{l}\stackrel{L}{\circ} \\
\stackrel{n}{m}\end{array}$ & ֻ̃ & $\begin{array}{l}\text { mo } \\
\stackrel{0}{N} \\
\stackrel{0}{0}\end{array}$ & $\frac{\overline{5}}{\sim}$ & î̀ & 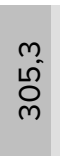 & 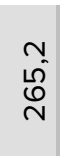 & $\begin{array}{l}0 \\
\vdots \\
\stackrel{\infty}{\infty}\end{array}$ & 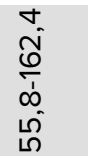 \\
\hline 일 & - & 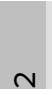 & 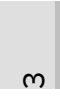 & $\nabla$ & 10 & 6 & 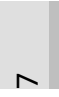 & $\infty$ & $\sigma$ & 으 & $\frac{\xi}{\mathrm{E}}$ \\
\hline
\end{tabular}


conditions for the functioning in the physiological mode of all cells of the body, especially brain cells.

Explicit pathological changes: the development of painful reactions, severe anxiety of animals during the penetration of bott through the skin, the formation of wounds in the places of the larvae insertion through the skin, the exudation of extracts with dermatolytic properties by the larvae, extravasation of the exudate and blood cells, the occurrence of inflammatory processes, edema, changes in functions affected organs and tissues, the constancy of the interstitial fluid composition and physicochemical properties, the violation of the histohematogenous barrier of the organism. Those allow concluding that hypoderma is a factor in both concomitant and background disease, which plays a significant role in the emergence and unfavourable course of deuteropathy of viral and bacterial origin with the development of severe complications and death of the animal.

Considering the urgency of the cattle hypodermatosis problem and having studied a number of questions on this issue, we assume that to some extent the results of our research are controversial in nature. In order to objectively highlight the pathogenicity of parasites and the parasitifer's protective reaction, especially in associative animal diseases, or mixed infestations, these questions are needed to be deep and detailed studied and analyzed, generalized and compared with the data of other scientific researchers.

However, taking into account a certain novelty of this research, in conclusion, It worth mentioned that the obtained research results provide an opportunity for a deeper assessment of the homeostasis and dynamic equilibrium of the organism of animals during cattle hypodermatosis, in order to fully compensate for the impairments of the body's physiological ability to self-regulate (sanogenesis), overcome the impact of pathogenic agents, the effectiveness of treatment and preventive measures, and therefore reduce the economic damage caused livestock.

\section{References}

[1] Ado, A.D., Ado, M.A., Pytskii, V.I. (2000). Pathological physiology. Moscow: Triad X, $574 \mathrm{p}$.

[2] Vasilieva, E.A. (1985). Clinical biochemistry of agricultural animals. Moscow: Agropromizdat, $342 \mathrm{p}$.

[3] Kudriavtsev, A.A. (1952). Blood tests in veterinary diagnostics. Moscow: Gosud. publishing house S.-H. lit., 375 p. 
[4] Kamarly, A.P. (1968). Materials for the study of the hypodermic gadfly of cattle in Kyrgyzstan. Tr. Kirghiz. In-t livestock and veterinary medicine, vol. 18, pp. 232--241.

[5] Dmitriev, V.M. (1965). On the loss of milk production of cows and weight gain of young stock caused by cattle hypoderma in Yakutia. Tr. Yakut. NIISH, vol. 12, pp. 87.

[6] Kunichkin, G.I. (1968). Some features of subcutaneous invasion of cattle in the AlmaAta region. Bulletin of science, no. 2, pp. 53--59.

[7] Garstukova, L.G. (2014). Visual histology. MIA, pp. 241.

[8] Vatsaev, Sh.V. (2008). Hypodermatosis of cattle (epizootology, species composition, population ecology) and the development of measures to combat it in the Chechen Republic. PhD dissertation. St. Peterburg, $128 \mathrm{p}$.

[9] Beesley, W.N. (1969). Observations on the biology of war ox fly (hypoderma Diptera, Oestridae). Dermotic properties of larval extracts. Ann. Trop. Med. and Parasitol, no. 63. pp. 157--160.

[10] Vatsaev, Sh.V. (2008). Hypodermatosis of bovine cattle (epizootology, species composition, population ecology) and the development of measures to combat it in the Chechen Republic. PhD dissertation thesis. St. Peterburg, $22 \mathrm{p}$.

[11] Vatsaev, Sh.V., Chernykh, O.Iu., Lysenko, A.A., Konovalov, M.G. (2017). Evaluation of biochemical indices of blood in case of modular dermatitis of cattle in the Chechen Republic. Scientific journal Proceedings of the Kuban State Agrarian University, no. 2(65), p. 101--107.

[12] Lysenko, I.O. (2009). Ecological foundations of the functioning of the parasite-host system in case of farm animal entomoses. PhD dissertation thesis. 